\title{
Identification of estrogen target genes in human neural cells
}

\author{
Adriana Maggi*, E. Vegeto, A. Brusadelli, S. Belcredito, G. Pollio, P. Ciana \\ Center Milan Molecular Pharmacology Laboratory, Institute of Pharmacological Sciences, University of Milan, Via Balzaretti 9 , \\ 20133 Milan, Italy
}

\begin{abstract}
In mammals, estrogens have a multiplicity of effects ranging from control of differentiation of selected brain nuclei, reproductive functions, sexual behavior. In addition, these hormones influence the manifestation of disorders like depression and Alzheimer's. Study of the cells target for the hormone has shown that estrogen receptors (ERs) are expressed in all known neural cells, including microglia. In view of the potential interest in the use of estrogens in the therapy of several pathologies of the nervous system, it would be of interest to fully understand the mechanism of estrogen activity in the various neural target cells and get an insight on the molecular means allowing the hormone to display such a variety of effects. We have proposed the use of a reductionist approach for the systematic understanding of the estrogen activities in each specific type of target cell. Thus, we have generated a model system in which to study the activation of one of the known (ERs), estrogen receptor alpha. This system allowed us to identify a number of novel genes which expression may be influenced following the activation of this receptor subtype by estradiol $\left(\mathrm{E}_{2}\right)$. We here report on data recently obtained by the study of one of these target genes, nip 2, which encodes a proapoptotic protein product. We hypothesize that nip 2 might be an important molecular determinant for estrogen anti-apoptotic activity in cells of neural origin and represents a potential target for drugs aimed at mimicking the $\mathrm{E}_{2}$ beneficial effects in neural cells. (C) 2000 Elsevier Science Ltd. All rights reserved.
\end{abstract}

Keywords: Estradiol; Estrogen receptors; Neuroblastoma; SK-ER3; Apoptosis; Nip2; Bcl-2

\section{Introduction}

In the last decade, evidence has been accumulated that the role of estradiol $\left(\mathrm{E}_{2}\right)$ in the mammalian central nervous system (CNS) goes far beyond the control of reproductive functions. $\mathrm{E}_{2}$ acts both in developing and in mature brain; during the differentiation of the nervous system it seems to regulate the differentiation of selected subsets of neurons [4]; in the mature brain $\mathrm{E}_{2}$ has a beneficial influence on memory mechanisms $[28,39]$ and on affective behavior [51] and it delays the onset of neurodegenerative disorders like Alzheimer's disease $[19,45,10,13,26]$. The understanding of the molecular mechanisms supporting $\mathrm{E}_{2}$ positive effects would be of interest for the development of novel, specific drugs. However, the multiplicity of estrogen functions in neural cells reflects a complexity of action which limits the elucidation of its activities in molecular terms.

\footnotetext{
* Corresponding author. Tel.: + 39-02-20488375; fax: + 39-0220488249.

E-mail address: adriana.maggi@unimi.it (A. Maggi).
}

\section{1. $E_{2}$ may modulate neural cell activities through a variety of mechanisms}

The factors contributing to heterogeneous responses to $E_{2}$ in the nervous system are due to, (a) the multiplicity of estrogen receptors (ERs); (b) the nature of estrogen target cells; (c) the heterogeneity of signals which can activate intracellular ERs.

\subsubsection{Multiplicity of ERs}

It is well known that estrogens bind intracellular receptors members of a superfamily of hormonally-regulated transcription factors [47]. So far, two estrogen binding proteins have been described and named estrogen receptor $\alpha$ and $\beta$ (ER $\alpha$ and ER $\beta)[27,25,46,15]$. Both receptors reside in the target cell nucleus in a complex together with inhibitory proteins (heat shock proteins, such as Hsp90 and others).

The cognate hormone by binding the receptor determines the release of the inhibitory proteins; the estrogenER complex can at this point recognize specific 
DNA sequences (named estrogen responsive elements) in the promoter of target genes, whereby recruits the proteins of the transcription apparatus and triggers the synthesis of specific mRNAs. Alternatively, the ligandactivated receptors without binding to the DNA may directly interact with elements of the transcription machinery and modulate the activity of other transcription factors (e.g. NFkB, AP-I, SFRE [43,49]. The genes coding for $E R \alpha$ and $\beta$ share a high degree of structural homology [27], particularly in the DNA binding (96\%) and in the hormone binding (53\%) domains. The N-terminus is the least homologous $(30 \%)$; it is conceivable that this domain might establish distinct interactions with the proteins of the transcription apparatus and be responsible for a differential activity of the two receptors. So far, however, very little experimental evidence supports a different role of the two receptors once expressed in the same cell system. To verify whether the two receptors have a differential function, we studied a very well known effect of $E_{2}$ in neural cells, neurite sprouting. By transient transfection of SK-N-BE cells with one of the two receptors at a time we demonstrated that, in the same cell, $\mathrm{E}_{2}(1 \mathrm{nM})$ induced a significantly different morphology in cells expressing
$\mathrm{ER} \alpha$ or $\beta$ (Fig. 1). This observation suggests that the two receptors have a distinct effect on the same target cell. We actually proved that this is indeed the case by cotransfecting with $\mathrm{ER} \alpha$ or $\beta$ dominant negative mutants of the small $\mathrm{G}$ protein Raclb, known to play an important role in microtubule assembly. This experiment demonstrated that the signaling pathway of $E R \alpha$, but not ER $\beta$, involves this small $G$ protein further substantiating our hypothesis (Fig. 2) [36]. In addition to the above mentioned intracellular receptors, several authors have recently proposed the existence of membrane receptors for estrogens [32] Smith et al., 1989, $[50,33,18,38]$, the evidence for this hypothesis being electrophysiological studies which indicate a functional link between membrane $\mathrm{E}_{2}$-binding proteins and calcium channels. There are also a number of studies showing $\mathrm{E}_{2}$-dependent activation of other transduction signaling molecules (cAMP, [17], $\mathrm{Ca}^{2+}$ [22,21], inositol3-phosphate kinase, diacylglicerol, src [5], CREB, ERK-1, ERK-2 [44] further suggesting the possibility that $\mathrm{E}_{2}$ binds to acceptor sites located in the cytoplasmic membrane.

These putative membrane receptors, however, are still unknown from the biochemical point of view. $\beta$ GAL
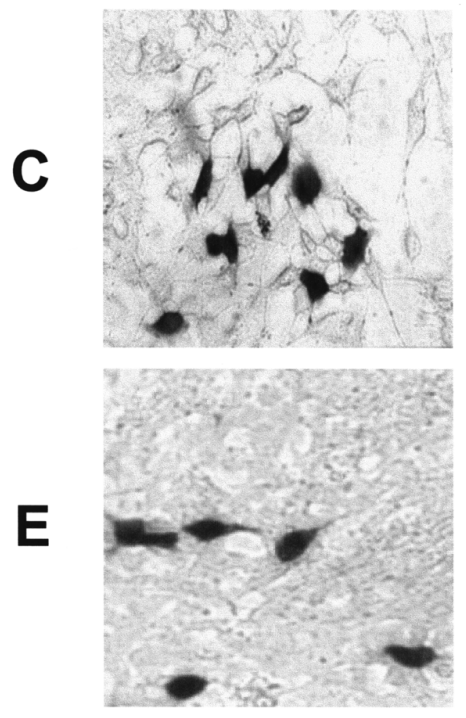

$E R \alpha$
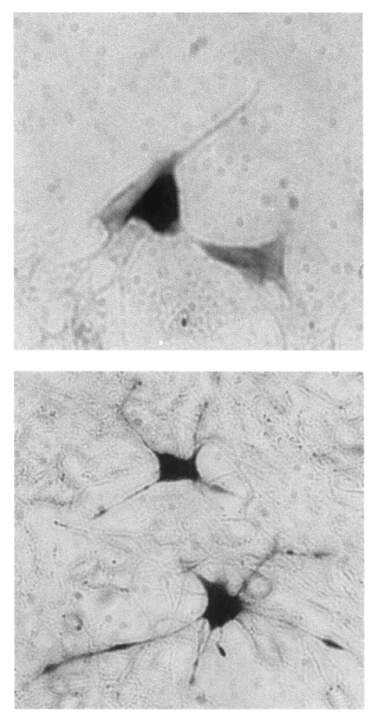

$\operatorname{ER} \beta$
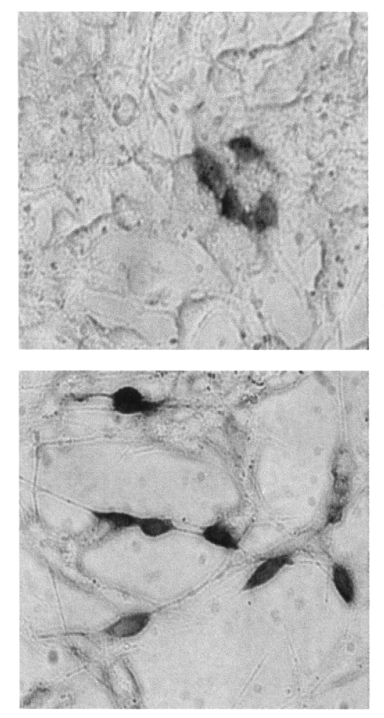

Fig. 1. Transient transfection of ER $\alpha$ or $\beta$ cDNA results in a differential morphogenetic response to estradiol of neuroblastoma SK-N-BE cells. The experiment was carried out by transient transfection of SK-N-BE cells with ER or ER $\beta$ cDNA together with $\beta$ GAL DNA to identify the cells positively transfected [36]. As we showed also with stable transfections, the estrogen-dependent activation of SK-N-BE cells expressing ER $\alpha$ results in a morphological change which can be quantitated by assessing the extent of neurite elongation and the number of neurites generated at a fixed day (e.g. sixth day following the treatment with the hormone). The morphological change induced by estradiol was significantly different in cells transfected with ER $\beta$. In this case, SK-N-BE morphological differentiation lead to the generation of uni- or bi-polar cells with morphology clearly distinguishable from cells transfected with the ER subtype. Upper panels: SK-N-BE cells transiently transfected with plasmids coding for $\beta$ GAL alone (left), ER and $\beta$ GAL (middle), ER $\beta$ and $\beta$ GAL (right). Lower panels: The cells transfected as above were treated for 6 days with $1 \mathrm{nM} \mathrm{E}_{2}$. ER $\alpha$-expressing cells (middle) acquire a star-shaped morphology with an average of four to five neurites per cell, while ER $\beta$-transfected cells (right) show a bipolar structure with a maximum of two neurites per cell. 


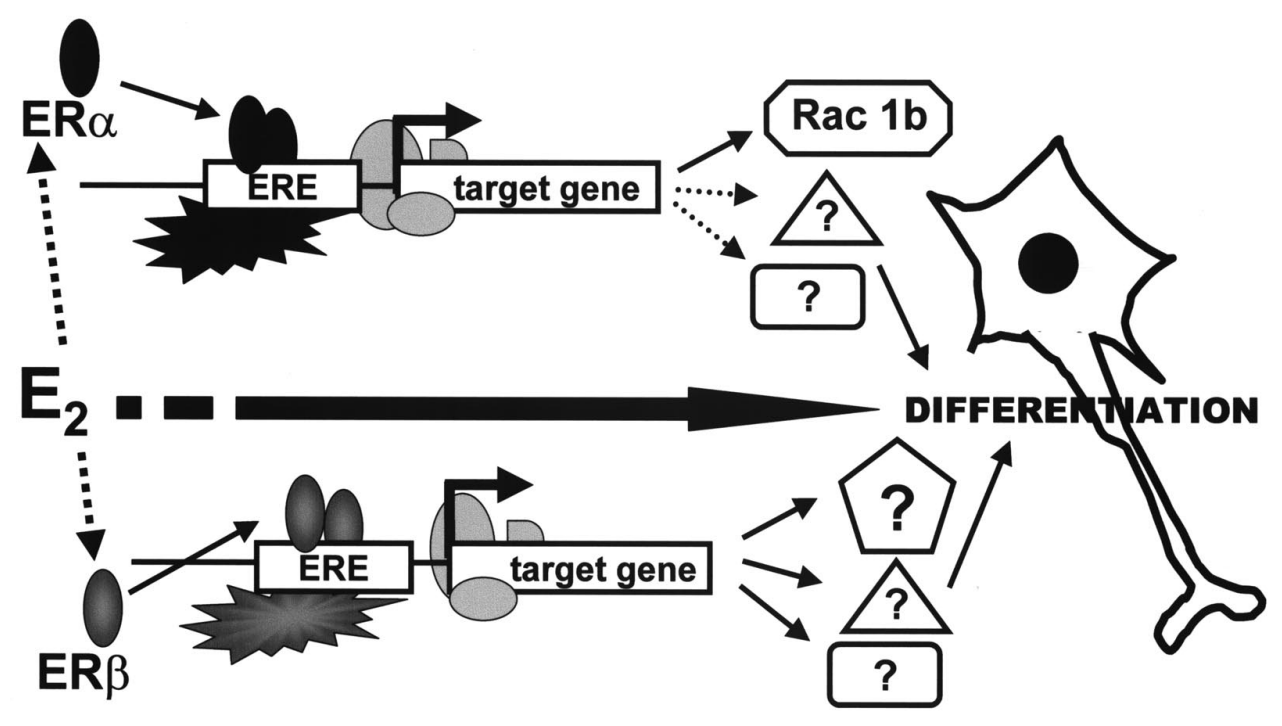

Fig. 2. In SK-N-BE cells different signal transduction molecules are responsible for the estrogen-dependent morphological changes. Transfection studies carried out with dominant negative mutants of small $\mathrm{G}$ proteins show that the morphological changes induced by $\mathrm{E}_{2}$ require active Raclb only in cells transfected with ER $\alpha$. The presence of dominante negative mutants of Raclb or Racla does not interfere with the morphological changes induced by activated $\operatorname{ER} \beta[36]$.

\subsubsection{All neural cell types may be target for estrogen activity}

Intracellular ERs can be found in all the neural cells, neurons and glial cells like oligodendrocytes and astrocytes $[23,40]$. In addition, recent, unpublished results from our laboratory, show that ERs are present also in rat microglial cells (Vegeto et al., unpublished data). Interestingly, localization studies indicate that $\mathrm{ER} \alpha$ and $\beta$ are generally expressed in different areas of the CNS $[41,42,3]$. It is conceivable, therefore, that in each specific target cell the estrogen triggers differential responses by activating selected target genes.

\subsubsection{Activation of ER in the absence of the cognate ligand}

Studies originally carried out in O'Malley's laboratory [37] and then by several other authors $[20,6,30,24,34,35]$ have shown that $\mathrm{ER} \alpha$ can be transcriptionally activated by neurotransmitters and growth factors also in the absence of the cognate ligand. In particular, dopamine [37], insulin, IGF-1 [30] and EGF [20] may control ER $\alpha$ transcriptional activity, possibly by phosphorylation of the receptor itself or of the coactivators/repressors interacting with it $[6,24,35]$. This interaction between intracellular and membrane receptors has been referred to as cross-talk (Fig. 3).

In view of the number of cells and genes targeted by this multifunctional receptor, the finding of differential mechanisms controlling its transcriptional activation leads to hypothesize that the above-mentioned crosstalk has evolved in order to limit the large ER potential by appropriate, differential hormone stimuli. We have proposed that this mechanism may be of relevance especially during the differentiation of the CNS [34] by allowing IGF-I to activate the ER. This would explain why, at least in rat, ERs are synthesized in several brain areas very early during the differentiation of the CNS while the high levels of circulating alpha-fetoproteins restrain estrogen access to the target cells [48].

\subsection{SK-ER3 neuroblastoma cells, a tool for the understanding of the molecular events induced by estrogens in neural cells}

The obvious consequence to what is said above is that the understanding of the molecular events triggered by the hormone-receptor complex in the whole brain tissue is not informative because any effect on target gene activities could represent the summation of a series of responses to the hormone in the various target cells. On this line of thought, a few years ago we proposed to generate a neuroblastoma cell line in which the activities of a single receptor (ER $\alpha$ ) [29] could be systematically studied in a specific cell system. To this goal, we stably transfected hER $\alpha$ cDNA in the human neuroblastoma cell line (SK-N-BE). We then characterized the cell line generated (Fig. 4) and (i) proved that it contains a number of receptors similar to other estrogen target cells (about 200 fmoles/mg cytosolic protein), (ii) that the hormone and DNA binding activity of the transfected receptors are indistinguishable from those previously reported in other cell lines and (iii) that the receptor is transcriptionally active [29]. Interestingly, our studies showed that in the SK-ER3 cell line the $\mathrm{E}_{2}$-dependent activation of $\mathrm{ER} \alpha$ results in growth arrest and differentiation towards the dopamin- 
ergic phenotype [1,2]. In view of the close links between the dopaminergic system and estrogen responsive cells in the CNS we proposed that the cell line we generated might recapitulate at least some of the events occurring during the differentiation of the CNS and continued our studies with the identification of genes regulated by estrogens in cells of neural origin. The technique applied was differential display PCR. We were able to isolate 11 DNA fragments representing genes modulated by $\mathrm{E}_{2}$, in SK-ER3 model system [14].

The question thus arising, regarded the physiological relevance of the genes identified in $\mathrm{E}_{2}$ action in neural cells.

\subsubsection{Nip2, a protein product whose expression correlates with cell death}

One of the genes whose expression was negatively modulated by $\mathrm{E}_{2}$, nip 2 , had been described earlier by Boyd [11] as coding for a Bcl-2 binding protein. We, therefore, initiated a series of experiments aimed at clarifying the role of nip 2 in cell activities.

1.2.1.1. Overexpression of nip 2 correlates with cell death. We initially observed the consequences of nip 2 overexpression in neuroblastoma cells. A series of transient transfections proved that nip 2 overexpression resulted in rapid cell death. The effect was dose-dependent [31] and could be blocked by Bcl-2 coexpression [9]. Further proof of the correlation between cell death and overexpression of nip 2 was obtained by measuring the content of nip $2 \mathrm{mRNA}$ in cells exposed to toxic stimuli. All the neurotoxic agents, glucose deprivation, calcium ionophore, $\beta$-amyloid peptide, determined a rapid increase in nip 2 expression which was then followed by the onset of pre-apoptotic events, like change in membrane polarity, and by cell death.

\subsubsection{2. $E_{2}$ down regulates nip 2 expression and blocks} neuroblastoma cell apoptosis. In SK-ER3 cells, treatment with $10 \mathrm{nM} \mathrm{E} E_{2}$ results in a significant decrease of nip 2 mRNA levels. Time course studies show that this effect is maximal at $4 \mathrm{~h}$ and then decreases with time. At $24 \mathrm{~h}$ after the treatments, nip 2 mRNA levels are back to control values [31]. Interestingly, in the same study, in a time course experiment taking into consideration the efficacy of $\mathrm{E}_{2}$ anti-apoptotic activity we showed that $\mathrm{E}_{2}$ may counteract the effect of neurotoxic agents only if it is administered before the toxic compounds and the protective effect of $E_{2}$ is maximal when given $16 \mathrm{~h}$ before the toxic insult. These observations led us to hypothesize that the down-modulation of nip 2 expression might be instrumental in the anti-apoptotic activity of $\mathrm{E}_{2}$ in neuroblastoma cells.

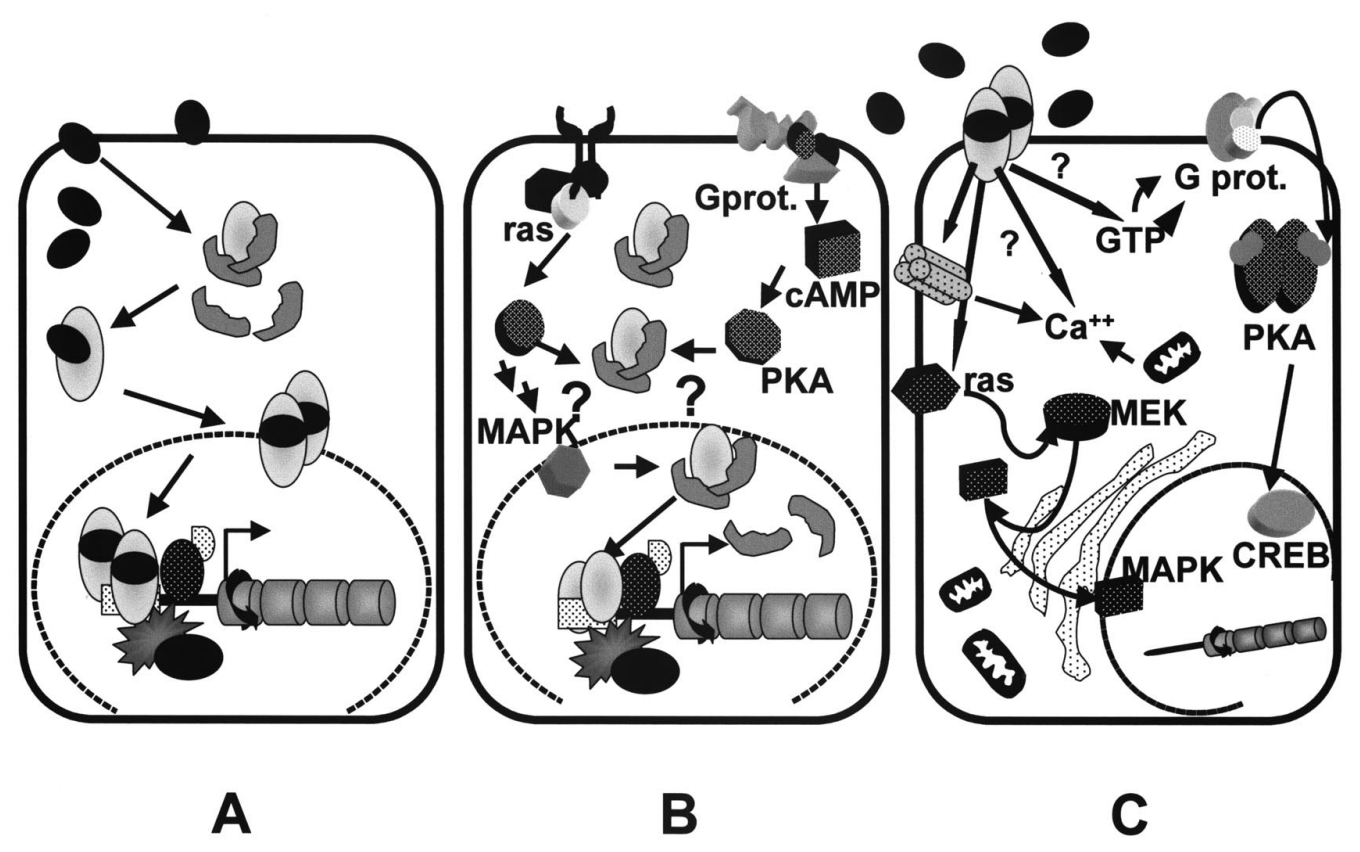

Fig. 3. Differential pathways involved in intracellular ER activation. Estrogen responsive genes can be modulated by activation of both intracellular and membrane receptors. The former can, in their turn, be activated through a ligand-dependent (A) or ligand-independent (B) pathway, which involves phosphorylation by different kinases, among which mitogen-activated protein kinases (MAPK). Membrane receptors (C) have not been biochemically characterized yet, but their existence is suggested by several lines of experimental evidence. Reports carried out by several authors in different estrogen target tissues suggest that estrogens may elicit very rapid (observed in ms) intracellular changes, which cannot be the result of a genomic action of the $\mathrm{E}_{2}$-ER complex. 


\section{CHARACTERISTICS OF THE} SK-ER3 CELL LINE:

\section{SK-ER3}

\section{- generated by stable transfection of $\mathrm{hER} \alpha$ in the neuroblastoma cell line SK-N-BE}
- expresses physiological levels of $\mathrm{hER} \alpha \quad(200 \mathrm{fmol} / \mathrm{mg}$ cytosolic proteins)
- expresses hERa with a DNA binding affinity of $0.2 \mathrm{nM}$
- expresses transcriptionally active hER $\alpha$ (Ma et al., 1993)
- $E_{2}$ treatment induces differentiation of the SK-ER3 cells towards a dopaminergic phenotype (Agrati et al., 1997a, 1997b)
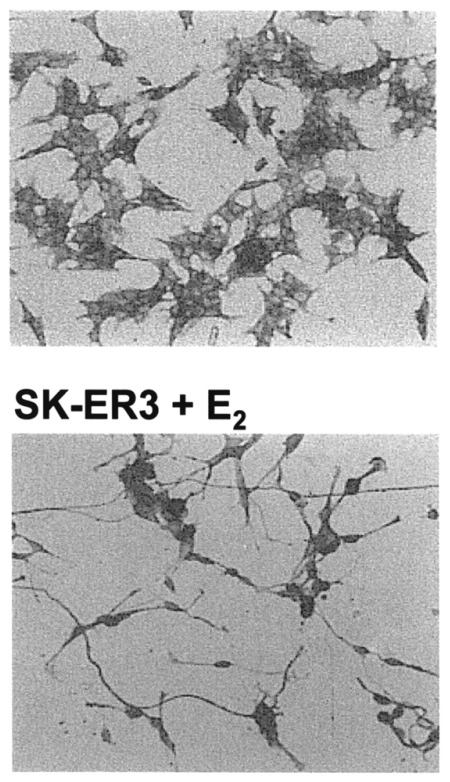

Fig. 4. The SK-ER3 neuroblastoma cell line as a model system for the study of estrogen effects in neural cells. The ER $\alpha$ expressed in SK-ER3 cells has ER $\alpha$ hormone-binding, DNA-binding and transcriptional activities identical to other cells expressing the receptor. Prolonged treatment with $1 \mathrm{nM} \mathrm{E}_{2}(16 \mathrm{~h})$ induces a series of intracellular events resulting in a differentiation towards a dopaminergic phenotype. Photographs on the right show the morphological differentiation of SK-ER3 cells 12 days after treatment with $\mathrm{E}_{2}$; the intense staining with anti-tyrosine hydroxylase antibodies show that SK-ER3 cells have acquired a dopaminergic phenotype [1,2].

\section{Discussion}

In the latest years, several authors have shown that $\mathrm{E}_{2}$ exerts anti-apoptotic activity in neural cells exposed to a variety of toxic insults $[7,19,8,16]$. The mechanisms involved in this activity is still controversial since several authors favor a non genomic-, while others a genomic-mediated effect of the hormone. Our studies indicate that $\mathrm{E}_{2}$ may modulate the synthesis of factors relevant in the apoptotic cascade of events and therefore point to the importance of $\mathrm{E}_{2}$-dependent genomic effects in neural cell protection against toxic stimuli. While the effects of $\mathrm{E}_{2}$ on nip2 activity await to be further studied in in vivo models, it is important to underlay that the neuroprotective effects of estrogens may be the result of a series of activities exerted on the different cell types present in the CNS. For instance, estrogens may enhance the synthesis and secretion of growth factors from glial cells as well as exert antiinflammatory activities in microglia [12]. These activities would contribute to enhance the survival of neurons and to limit the accumulation of toxic substances, respectively. We are therefore focusing on the effect of the hormone also in cells other than neurons.

Our studies provide some background for the understanding of the molecular signaling underlying $\mathrm{E}_{2}$ protective effects, which might be of interest also for cells other than neural (e.g. mammary gland). The finding of specific target for estrogen action may lead to the design of novel drugs aimed at reproducing the beneficial effects of the hormone, in the absence of the undesired ones.

\section{Acknowledgements}

The studies presented here have been supported by the European Community Programme BIOMED (Contract no. BMH4-CT97-2286), Istituto Superiore di Sanita' Multiple Sclerosis program, National Council for Research, Finalized Project Biotechnology, MURST 40\%; Telethon Onlus (E600), Italian Association for Cancer Research (AIRC).

\section{References}

[1] P. Agrati, M. Garnier, C. Patrone, G. Pollio, S. Santagati, E. Vegeto, A. Maggi, SK-ER3 neuroblastoma cells as a model for the study of estrogen influence on neural cells, Brain. Res. Bull. 44 (1997a) 519-523.

[2] P. Agrati, Z.Q. Ma, C. Patrone, G.B. Picotti, C. Pellicciari, G. Bondiolotti, M.G. Bottone, A. Maggi, Dopaminergic phenotype induced by estrogens in a human neuroblastoma cell line, Eur. J. Neurosci. 9 (1997b) 1008-1016. 
[3] P. Agrati, L. Bolzoni, A. Brusadelli, P. Ciana, E. Marini, C. Meda, C. Patrone, M.C. Penlington, G. Pollio, M. Rebecchi, R.H. Sialino, E. Vegeto, A. Maggi, In vitro study of effects of estrogens on estrogen receptor-transfected neuroblastoma cells, in: A. Matsumoto (Ed.), Sexual Differentiation of the Brain, CRC Press, Boca Raton, FL, 2000, pp. 21-32.

[4] A.P. Arnold, R.A. Gorski, Gonadal steroid induction of structural sex differences in the central nervous system, Annu. Rev. Neurosci. 7 (1984) 413-442.

[5] S.F. Arnold, J.D. Obourn, H. Jaffe, A.C. Notides, Phosphorylation of the human estrogen receptor on tyrosine 537 in vivo and by Src family tyrosine kinases in vitro, Mol. Endocrinol. 9 (1995) 24-33.

[6] S.M. Aronica, B.S. Katzenellenbogen, Stimulation of estrogen receptor-mediated transcription and alteration in the phosphorylation state of the rat uterine estrogen receptor by estrogen, cyclic adenosine monophosphate and insulin-like factor-1, Mol. Endocrinol. 7 (1993) 743-752.

[7] C. Behl, M. Widmann, T. Trapp, F. Holsboer, 17-beta estradiol protects neurons from oxidative stress-induced cell death in vitro, Biochem. Biophys. Res. Commun. 216 (1995) 473-482.

[8] C. Behl, T. Skutella, F. Lezoualc'h, A. Post, M. Widmann, C.J. Newton, F. Holsboer, Neuroprotection against oxidative stress by estrogens: structure-activity relationship, Mol. Pharmacol. 51 (1997) $535-541$.

[9] S. Belcredito, A. Brusadelli, A. Maggi, Estrogens, apoptosis and cells of neural origin. J Neurocytol, 2000, in press.

[10] S.J. Birge, The role of estrogens in the treatment of Alzheimer's disease, Neurology 48 (1997) 36-41.

[11] J.M. Boyd, S. Malstrom, T. Subramanian, L.K. Venkatesh, U. Schaeper, B. Elangovan, C. D'Sa-Eipper, G. Chinnadurai, Adenovirus $\mathrm{E} 1 \mathrm{~B} 19 \mathrm{kDa}$ and $\mathrm{Bcl}-2$ proteins interact with a common set of cellular proteins, Cell 7 (1994) 341-351.

[12] S. Cuzzocrea, S. Santagati, L. Sautebin, E. Mazzon, G. Calabro, I. Serraino, A.P. Caputi, A. Maggi, 17Beta-estradiol antiinflammatory activity in carrageenan-induced pleurisy, Endocrinology 141 (2000) 1455-1463.

[13] P.M. Doraiswamy, F. Bieber, L. Kaiser, K.R. Krishnan, J. Reuning-Scherer, B. Gulanski, The Alzheimer's disease assessment scale: patterns and predictors of baseline cognitive performance in multicenter Alzheimer's disease trials, Neurology 48 (1997) 1511-1517.

[14] M. Garnier, D. Di Lorenzo, A. Albertini, A. Maggi, Identification of estrogen responsive genes in neuroblastoma SK-ER3 cells, J. Neurosci. 17 (1997) 4591-4599.

[15] V. Giguere, A. Tremblay, G.B. Tremblay, Estrogen receptor $\beta$ : re-evaluation of estrogen and antiestrogen signaling, Steroids 63 (1998) 335-339.

[16] P.S. Green, J. Bishop, J.W. Simpkins, 17 $\alpha$-estradiol exerts neuroprotective effects on SK-N-SH cells, J. Neurosci. 17 (1997) $511-515$.

[17] Q. Gu, R.L. Moss, 17ß-estradiol potentiates kainate-induced currents via activation of the cAMP cascade, J. Neurosci. 16 (1996) 3620-3629.

[18] Q. Gu, K.S. Korach, R.L. Moss, Rapid action of 17ß-estradiol on kainate-induced currents in hippocampal neurons lacking intracellular estrogen receptors, Endocrinology 140 (1999) 660666.

[19] H. Honjo, K. Tanaka, T. Kashiwagi, M. Urabe, H. Okada, M. Hayashi, K. Hayashi, Senile dementia - Alzheimer's type and estrogens, Horm. Metab. Res. 27 (1995) 204-207.

[20] D.M. Ignar-Trowbridge, K.G. Nelson, M.C. Bidwell, S.W. Curtis, T.F. Washburn, J.A. McLachlan, K.S. Korach, Coupling of dual signaling pathways: epidermal growth factor action involves the estrogen receptors, Proc. Natl. Acad. Sci. USA. 89 (1992) $4658-4662$.
[21] T. Improta-Brears, A.R. Whorton, F. Codazzi, J.D. York, T. Meyer, D.P. McDonnel, Estrogen-induced activation of mitogen-activated protein kinase requires mobilization of intracellular calcium, Proc. Natl. Acad. Sci. USA. 96 (1999) 4686-4691.

[22] M. Joëls, H. Karst, Effects of estradiol and progesterone on voltage-gated calcium and potassium conductances in rat CA1 hippocampal neurons, J. Neurosci. 15 (1995) 4289-4297.

[23] I. Jung-Testas, M. Renoir, H. Bugnard, G.L. Greene, E.E. Baulieu, Demonstration of steroid hormone receptors and steroid action in primary cultures of rat glial cells, J. Steroid Biochem. Mol. Biol. 41 (1992) 621-631.

[24] S. Kato, H. Endoh, Y. Masuhiro, T. Kitamoto, S. Uchiyama, H. Sasaki, S. Masushige, Y. Gotoh, E. Nishida, H. Kawashima, D. Metzger, P. Chambon, Activation of the estrogen receptor through phosphorylation by mitogen-activated protein kinase, Science 270 (1995) 1491-1494.

[25] B.S. Katzenellenbogen, K.S. Korach, A new actor in the estrogen receptor drama-enter ER $\beta$, Endocrinology 138 (1997) 861 862.

[26] C. Kawas, S. Resnick, A. Morrison, R. Brookmeyer, M. Corrada, A. Zonderman, C. Bacal, D.D. Lingle, E. Metter, A prospective study of estrogen replacement therapy and the risk of developing Alzheimer's disease: the Baltimore longitudinal study of aging, Neurology 48 (1997) 1517-1521.

[27] G.G. Kuiper, E. Enmark, M. Pelto-Huikko, S. Nilsson, J-Å. Gustafsson, Cloning of a novel receptor expressed in rat prostate and ovary, Proc. Natl. Acad. Sci. USA. 93 (1996) 5925-5930.

[28] V.N. Luine, Steroid hormone influences on spatial memory, Ann. NY Acad. Sci. 743 (1994) 201-211.

[29] Z.Q. Ma, E. Spreafico, G. Pollio, S. Santagati, E. Conti, E. Cattaneo, A. Maggi, Activated estrogen receptor mediates growth arrest and differentiation of a neuroblastoma cell line, Proc. Natl. Acad. Sci. USA. 90 (1993) 3740-3744.

[30] Z.Q. Ma, S. Santagati, C. Patrone, G. Pollio, E. Vegeto, A. Maggi, Insulin-like growth factors activate estrogen receptor to control the growth and differentiation of the human neuroblastoma cell line SK-ER3, Mol. Endocrinol. 8 (1994) 910-918.

[31] C. Meda, E. Vegeto, G. Pollio, A. Brusadelli, C. Patrone, C. Pellicciari, A. Maggi. Estrogen prevention of neural cell death correlates with decreased expression of the pro-apoptotic protein Nip2. J. Neuroendocrinol., 2000, in press.

[32] J. Nabekura, Y. Oomura, T. Minami, Y. Mizuno, A. Fukuda, Mechanism of the rapid effect of $17 \beta$-estradiol on medial amygdala neurones, Science 233 (1986) 226-228.

[33] T.C. Pappas, B. Gametchu, C.S. Watson, Membrane estrogen receptors identified by multiple antibody labeling and impededligand binding, Faseb J. 9 (1995) 404-410.

[34] C. Patrone, Z.Q. Ma, G. Pollio, P. Agrati, M.G. Parker, A. Maggi, Cross-coupling between insulin and estrogen receptor in human neuroblastoma cells, Mol. Endocrinol. 10 (1996) 499507.

[35] C. Patrone, E. Gianazza, S. Santagati, P. Agrati, A. Maggi, Divergent pathways regulate ligand-independent activation of ER alpha in SK-N-BE neuroblastoma and COS-1 renal carcinoma cells, Mol. Endocrinol. 12 (1998) 835-841.

[36] C. Patrone, G. Pollio, E. Vegeto, E. Enmark, I. De Curtis, J.A. Gustafsson, A. Maggi, Endocrinology 141 (2000) 1839-1845.

[37] R.F. Power, S.K. Mani, J. Codina, O.M. Conneely, B.W. O'Malley, Dopaminergic and ligand-independent activation of steroid hormone receptors, Science 254 (1991) 1636-1639.

[38] M. Razandi, A. Pedram, G.L. Green, E.R. Levin, Cell membrane and nuclear estrogen receptors (ERs) origin from a single transcript: studies of ERalpha and ERbeta expressed in Chinese hamster ovary cells, Mol. Endocrinol. 13 (1999) 307-319.

[39] M.M. Rodriguez, G.T. Grossberger, Estrogens as psychotherapeutic agents, Clin. Geriatr. Med. 14 (1998) 177-189. 
[40] S. Santagati, R.C. Melcangi, F. Celotti, L. Martini, A. Maggi, Estrogen receptor is expressed in different types of glial cells in culture, J. Neurochem. 63 (1994) 2058-2064.

[41] P.J. Shughrue, B. Komm, I. Merchentaler, The distribution of estrogen receptor-beta mRNA in the rat hypothalamus, Steroids 61 (1996) 678-681.

[42] P.J. Shughrue, M.V. Lane, I. Merchenthaler, Comparative distribution of estrogen receptor- $\alpha$ and $-\beta$ mRNA in the rat central nervous system, J. Comp. Neurol. 388 (1997) 507-525.

[43] G. Shyamala, M.C. Guiot, Activation of $\kappa$ b-specific proteins by estradiol, Proc. Natl. Acad. Sci. USA. 89 (1992) 10628-10632.

[44] M. Sing, G. Setalo, Jr., X. Guan, M. Warren, C.D. ToranAllerand, Estrogen-induced activation of mitogen-activated protein kinase in cerebral cortical explants: convergence of estrogen and neurotrophin signaling pathways, J. Neurosci. 19 (1999) $1179-1188$.

[45] M.X. Tang, D. Jacobs, Y. Stern, K. Marder, P. Schofield, B. Gurland, H. Andrews, R. Mayeux, Effect of estrogens during menopause on risk and age at onset of Alzheimer's disease, Lancet 348 (1996) 429-432.

[46] G.B. Tremblay, A. Tremblay, N.G. Copeland, D.J. Gilbert, N.A. Jenkins, F. Labrie, V. Giguere, Cloning, chromosomal localization, and functional analysis of the murine estrogen receptor beta, Mol. Endocrinol. 11 (1997) 353-365.

[47] M.J. Tsai, B.W. O'Malley, Molecular mechanisms of action of steroid/thyroid receptor superfamily members, Annu. Rev. Biochem. 63 (1994) 451-486.

[48] B. Vannier, J.P. Raynaud, Effect of estrogen on plasma binding on sexual differentiation of the rat phoetus, Mol. Cell. Endocrinol. 3 (1975) 323-337.

[49] P. Webb, P. Nguyen, C. Valentine, G.N. Lopez, G.R. Kwok, E. McInerney, B.S. Katzenellenbogen, E. Enmark, J-Å. Gustafsson, S. Nilsson, P.J. Kushner, The estrogen receptor enhances AP-1 activity by two distinct mechanisms with different requirement for receptor transactivation functions, Mol. Endocrinol. 13 (1999) 1672-1685.

[50] M. Wong, R.L. Moss, Electrophysiological evidence for a rapid membrane action of the gonadal steroid, $17 \beta$-estradiol, on CA1 pyramidal neurons of the rat hippocampus, Brain. Res. 543 (1991) $148-152$.

[51] K. Yaffe, G. Sawaya, I. Lieberburg, D. Grady, Estrogen therapy in postmenopausal women: effects on cognitive function and dementia, J. Am. Med. Assoc. 279 (1998) 688-695. 